\title{
DEVELOPMENT OF A NEW METHOD OF STORAGE AND MAXIMUM SEPARATION OF CHLOROPHILS FROM CHLOROPHYLCONTAINING VEGETABLES AT RECEPTION OF HEALTHFULL NANOPRODUCTS
}

\author{
Raisa Pavlyuk \\ Department of Technology processing of fruits, vegetables and milk \\ Kharkiv State University of Food Technology and Trade \\ 333 Klochkivska str., Kharkiv, Ukraine, 61051 \\ ktppom@ukr.net \\ Viktoriya Pogarska \\ Department of Technology processing of fruits, vegetables and milk \\ Kharkiv State University of Food Technology and Trade \\ 333 Klochkivska str., Kharkiv, Ukraine, 61051 \\ Valeriy Mikhaylov \\ Department of processes, devices and automation of food production \\ Kharkiv State University of Food Technology and Trade \\ 333 Klochkivska str., Kharkiv, Ukraine, 61051 \\ mykhailov@kharkov.com

\section{Olexandr Bessarab} \\ Department of Technology preservation \\ National University of Food Technologies \\ 68 Volodimirovska str., Kyiv, Ukraine, 01601 \\ tk_nuft@i.ua \\ Ludmila Radchenko \\ Kharkiv Trade-Economic Colledge of Kyiv \\ National University of Trade and Economics \\ 202 Klochkivska str., Kharkiv, Ukraine, 61045 \\ kharkiv@htek.com.ua \\ Aleksey Pogarskiy \\ Department of Technology processing of fruits, vegetables and milk \\ Kharkiv State University of Food Technology and Trade \\ 333 Klochkivska str., Kharkiv, Ukraine, 61051

\section{Oleksandr Telenkov} \\ Putivl College of Sumy National Agrarian University \\ 80 Lunocharskogo str., Putivl, Ukraine, 41500

\section{Anna Radchenko} \\ Kharkiv Trade-Economic Colledge of Kyiv \\ National University of Trade and Economics \\ 202 Klochkivskaya str., Kharkiv, Ukraine, 61045
}

Abstract

The aim of the work is the development of a new way of deep processing of chlorophyll-containing vegetables that gives a possibility not only to preserve chlorophylls a and $\mathrm{b}$ and other biologically active substances (BAS) of raw materials, but also 
to transform hidden bound (inactive) forms of chlorophyll in the free easy-digestible form at getting steam-thermally processed semi-products and healthy food products in the nanoform.

For achieving the aim, the complex effect of steam-thermal processing and mechanolysis at fine-dyspersed comminution using the new equipment was applied as an innovation for thermal processing and comminution.

There was developed the new method of getting healthy products of chlorophyll-containing vegetables (broccoli, spinach, Brussels cabbage, green leguminous haricot bean), steam-thermally processed (by hot steam) in the steam-convectional stove and fine-dyspersed with high contents of chlorophylls and other BAS and prebiotics. The method is based on the complex effect of processes of thermodestruction, mechanodestruction and non-enzymatic catalysis on raw materials at fine-dyspersed comminution. It was demonstrated, that at steam thermal processing of chlorophyll-containing vegetables $(\mathrm{CCV})$ in the steam-convectomat during 5 minutes, there takes place not only preservation of chlorophylls a and $\mathrm{b}$, but more full separation (in 1,33 ..1,4 times) from the hidden (bound) form, comparing with fresh vegetables. There was elucidated the mechanism of this process. The more full extraction of hidden forms of $\beta$-carotene ( 2 times more than in fresh CCV) takes place in parallel.

The essentially more effect of transforming hidden forms was revealed at fine-dyspersed comminution of steam-thermally processed CCV. It was demonstrated, that thermally processed nanoproducts of CCV contain 2...2,1 more chlorophylls a and b, $2,0 \ldots 3,3$ times more carotenoids in the bound form than fresh vegetables.

The quality of obtained new types of fine-dyspersated steam-thermally processed green products as puree and soups-purees of CCV exceeds one of known analogues by contents of chlorophylls a and b, $\beta$-carotene and other BAS, which are in nanosize easy-digestible form.

Using new types of fine-dyspersated purees of $\mathrm{CCV}$, there was developed the new green line of healthy nanoproducts: soups-purees, nanodrinks, nanosorbets, sauces-dressings, sauces-deeps, ice-cream, snacks and so on. It was demonstrated, that new products exceed existing analogues by BAS content (chlorophylls, $\beta$-carotene, L-ascorbic acid, phenol compounds).

Keywords: deep processing, BAS, fine-dyspersed puree, preservation of chlorophyll, steam-thermal processing, mechanolysis, chlorophyll-containing vegetables, healthy nanoproducts.

DOI: $10.21303 / 2504-5695.2018 .00616$

(C) Raisa Pavlyuk, Viktoriya Pogarska, Valeriy Mikhaylov, Olexandr Bessarab, Ludmila Radchenko, Aleksey Pogarskiy, Oleksandr Telenkov, Anna Radchenko

\section{Introduction}

Among biologically active substances (BAS) that favor immunity strengthening, the special place is occupied by chlorophylls [1]. According to the last data of Japanese scientists, "The base of human health is vegetable food, and chlorophyll is the base of vegetable food and whole vegetable world. Chlorophyll it is a product of solar energy that gives an impulse of movement and youth, penetrating the human organism" [2]. The content of chlorophyll in plants is $0,008 \ldots 0,8 \%$ [1].

According to the data of scientists of leading medical institutions of USA, Netherlands, India, Japan, Sweden, chlorophyll carries out many diverse protecting and regulatory functions in the human organism [2]. Among them, first of all, - cleaning (detoxication and elimination of harmful and toxic substances from the human organism); regulation of acidic-alkaline $\mathrm{pH}$-balance and hormones level in the organism. At the same time, immunity strengthening and also antibacterial, geroprotective effect and strengthening of vessels of the heart and brain. In the human organism chlorophyll blocks the action of cancirogens, protects DNA from lesions, caused by the effect of toxins, free oxidizing radicals. Chlorophyll is a natural means of cancer prophylaxis [3, 4].

Chlorophyll sources in population food are fresh chlorophyll-containing vegetables $(\mathrm{CCV})$ : broccoli, spinach, lettuce, dill, parsley and other and products of them. It is known, that essential losses of chlorophylls and other BAS take place at processing. That is why it is urgent to search for technological methods that result in preserving BAS of chlorophyll-containing vegetables and development of healthy nanoproducts with the high chlorophyll content [5].

Traditional technologies of processing CCV and other types of fruit-vegetable raw materials in ready products result in essential losses of chlorophyll and other BAS of fresh raw materials. It results in the unreasonable use of their biological potential. Processing losses are from 20 to $80 \%$ for different types of raw materials and different BAS [6]. That is why it is urgent to search 
for technological methods and to develop high technologies that allow to preserve and to use the quality of fresh raw materials.

The task of the work included the study of BAS complex of chlorophyll-containing vegetables as raw materials for obtaining healthy nanoproducts by the method of deep processing. This method is based on the complex effect of steam-thermal processing and mechanolysis at fine-dyspersed comminution. Its use at getting products of carotene-containing raw materials [7], and also mushrooms gave a possibility to preserve the biological potential of fresh raw materials maximally [8]. It was assumed, that the aforesaid method of deep processing allows to preserve the quality of $\mathrm{CCV}$ as contents of chlorophyll and other BAS and also to transform hidden bound (inactive) chlorophyll forms in the easy-digestible form at getting healthy nanoproducts.

\section{Materials and methods of the studies of contents of biologically active substances}

For achieving the set aim, the complex effect of steam-thermal processing and mechanolysis at fine-dyspersed comminution using the new equipment was used as an innovation for thermal processing and comminution for activation and transformation of hidden forms of BAS in the easy-digestible ones $[9,10]$.

The department of the technology of processing fruits, vegetables and milk of Kharkiv state university of food and trade together with the National university of food technologies (NUFT, city Kyiv), Kharkiv trade economy college of KNEU, Putyvl agrarian college developed healthy nanoproducts of chlorophyll-containing vegetables using the method of deep processing, offered by the authors.

The studies were carried out in the Kharkiv state university of food and trade (KNUFT, Ukraine) at the department of processing fruits, vegetables and milk, in the research laboratory of "Innovative cryo- and nanotechnologies of vegetable supplements and healthy products" with using for steam-thermal processing the steam-convectional stove UNOX SPA, series XVC (Italy), with 70 programs that differ from each other by regimes of technological processing: temperature, intensity and quantity of steam supply, circulation or blowing by wind (Fig. 1, a). The communitor Robot Coupe (France) was used for fine-dyspersed comminution (Fig. 1, b).
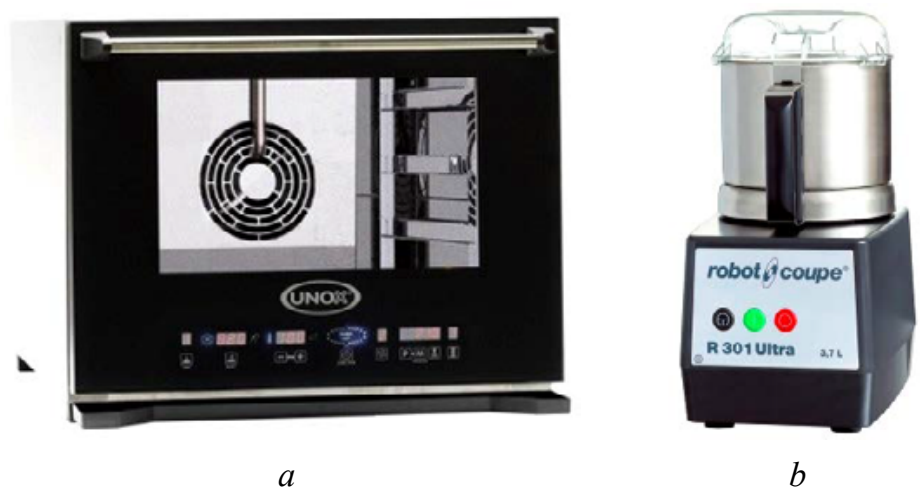

Fig. 1. Equipment, used at studies: $a$ - steam-convectional stove UNOX SPA series XVC (Italy); $b$ - Comminutor Robot Coupe (France)

Chlorophyll-containing vegetables: broccoli, spinach, Brussels cabbage, green leguminous haricot bean were used as raw materials (Fig. 2). At the same time healthy nanoproducts of green color, produced of chlorophyll-containing vegetables: fine-dyspersed purees, soups-purees, drinks, sorbets, dressings were used as research objects (Fig. 3).

The essential part of healthy products may be recommended for production at both big enterprises of food industry and ones of restaurant business and culinary departments of super-markets. 

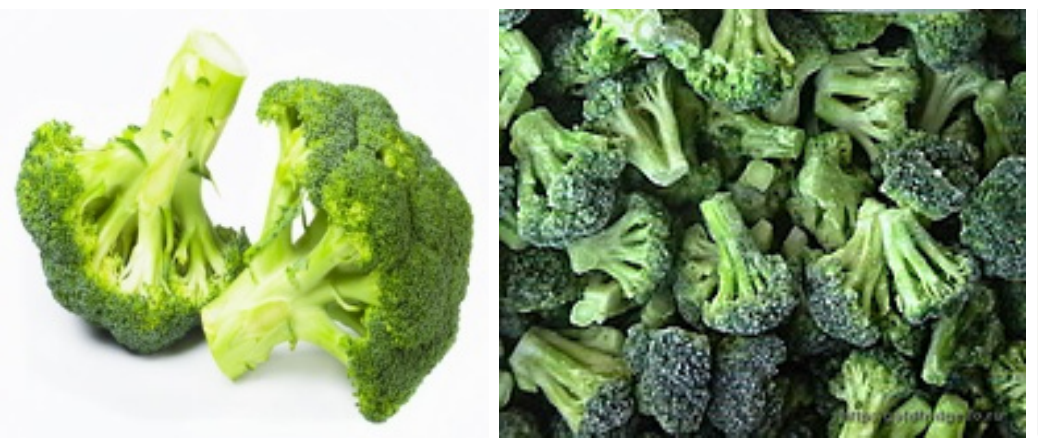

$b$

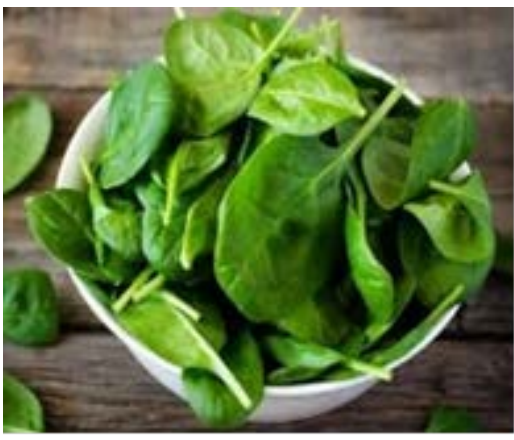

$d$

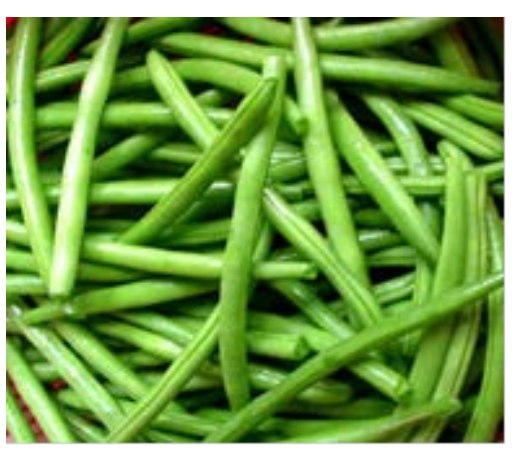

$g$

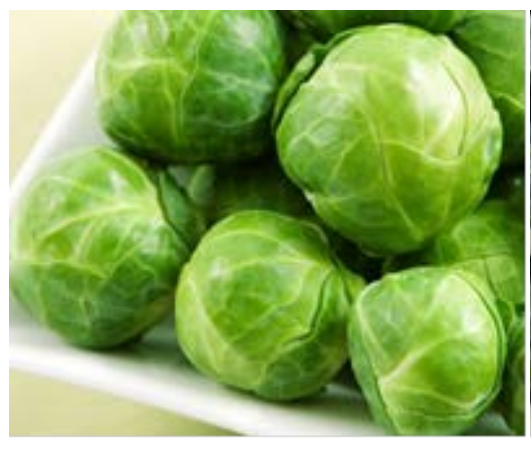

$j$

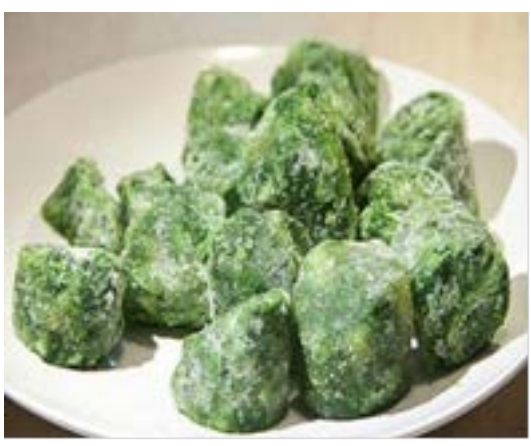

$e$

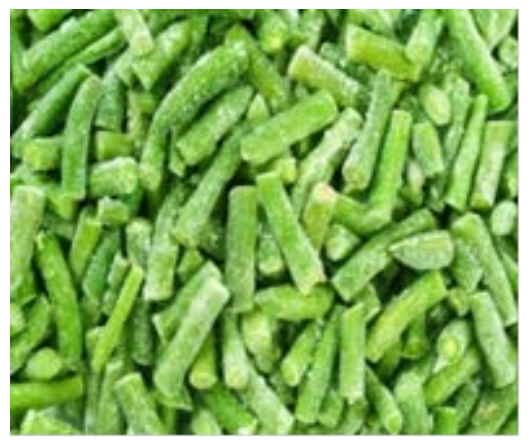

$h$

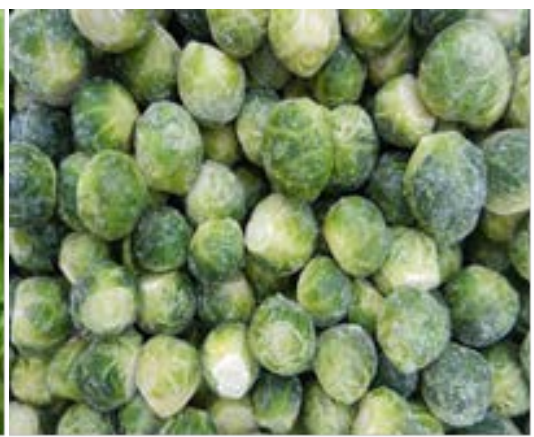

$k$
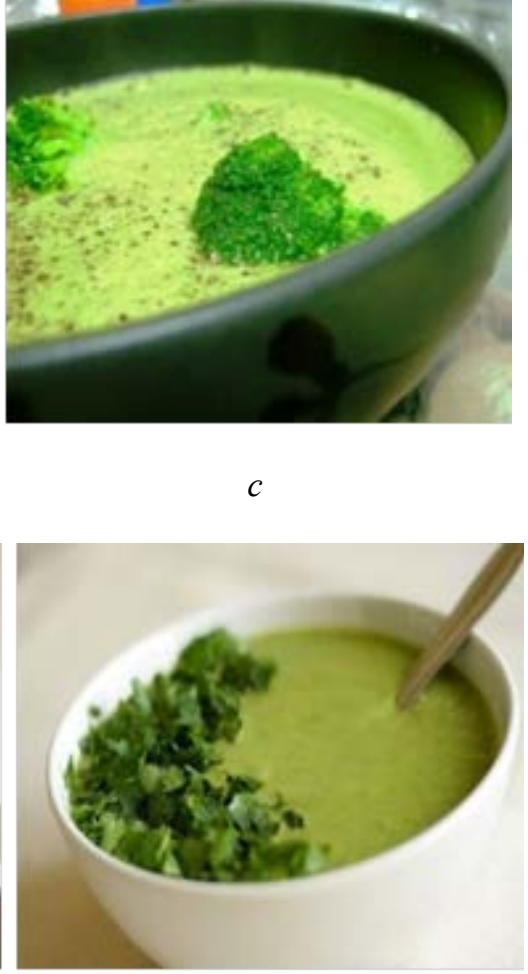

$f$

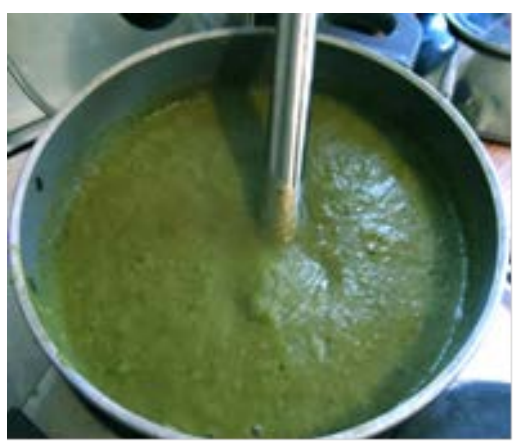

$i$

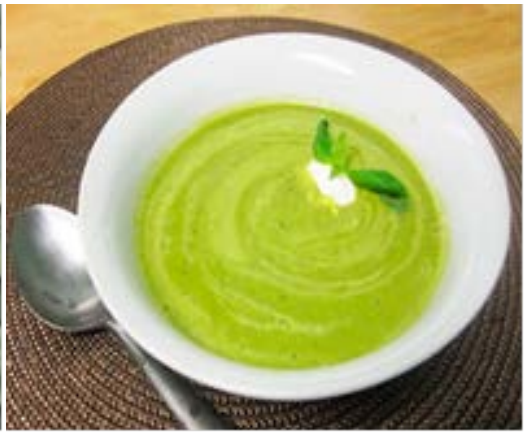

$l$

Fig. 2. Research objects: $a, b, c$ - fresh broccoli (a), frozen broccoli (b), puree of broccoli (c), $d, e, f$ - fresh spinach $(d)$, frozen $(e)$, puree of spinach $(f), g, h, i$ - green leguminous haricot bean $(g)$, frozen $(h)$, puree of green leguminous haricot bean $(i), j, k, l$ - fresh Brussels cabbage $(j)$, frozen $(k)$, puree of Brussels cabbage $(m)$ 


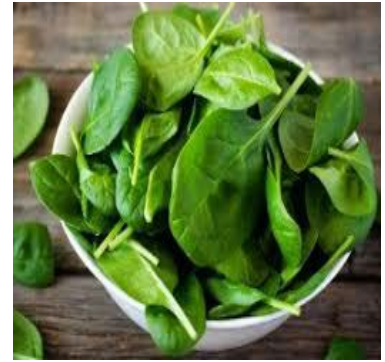

$a$

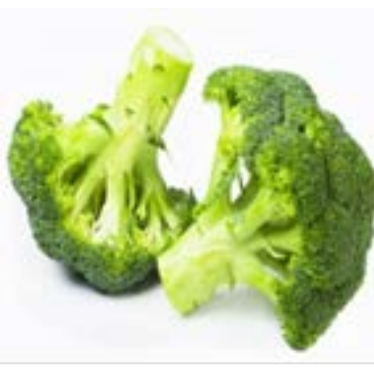

e

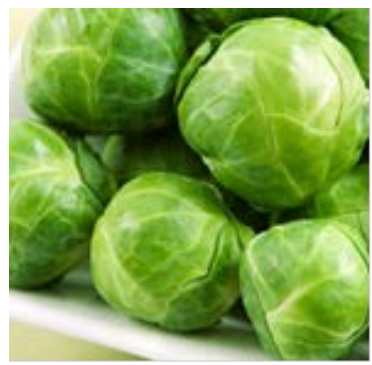

$i$

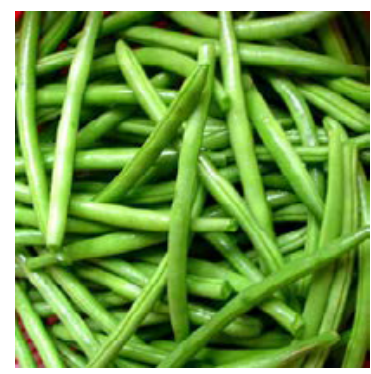

$m$

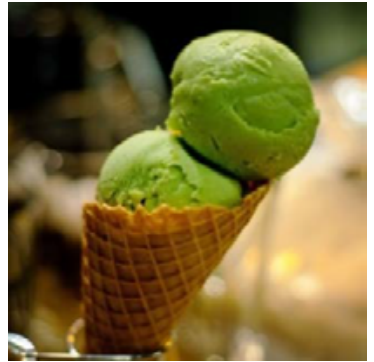

$b$

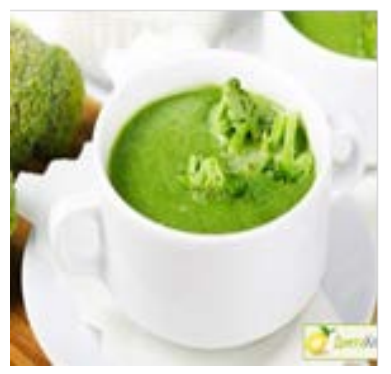

$f$

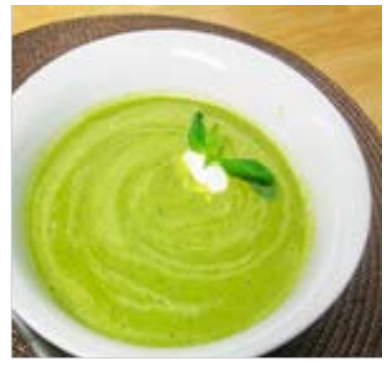

$j$

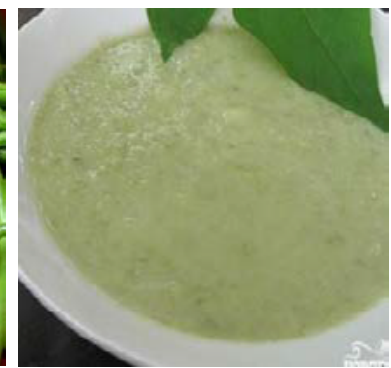

$n$

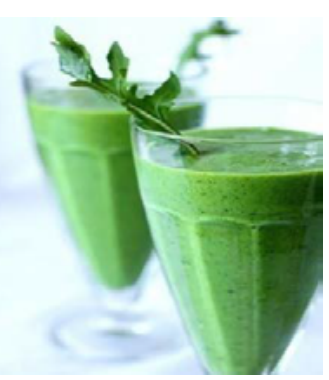

$c$

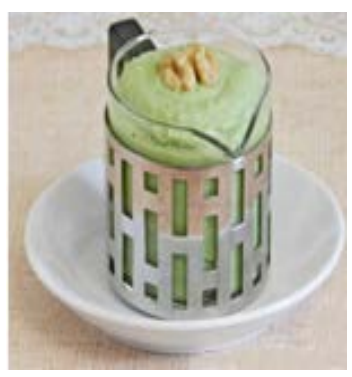

$g$

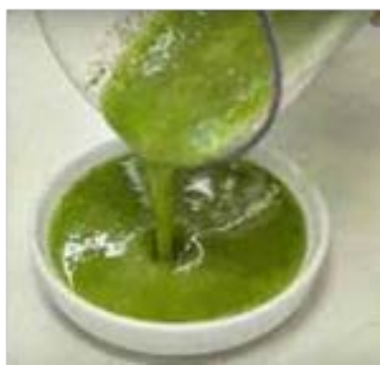

$k$

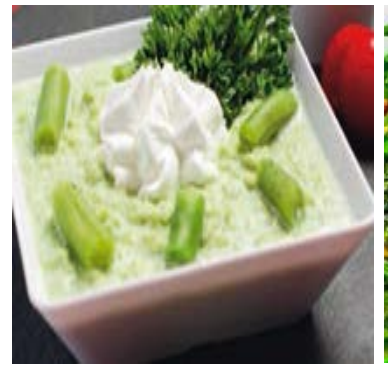

O

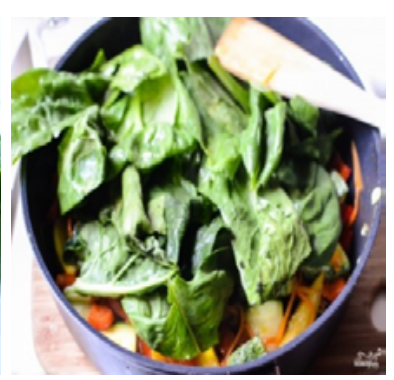

$d$

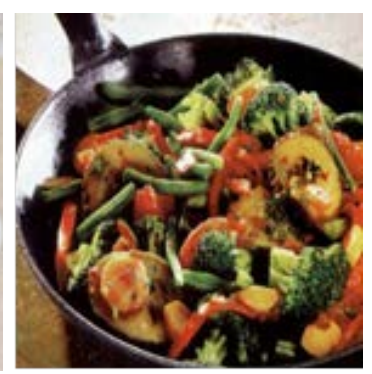

$h$

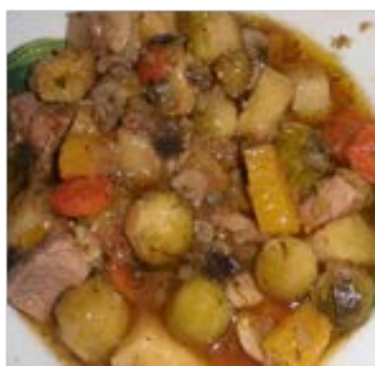

$l$

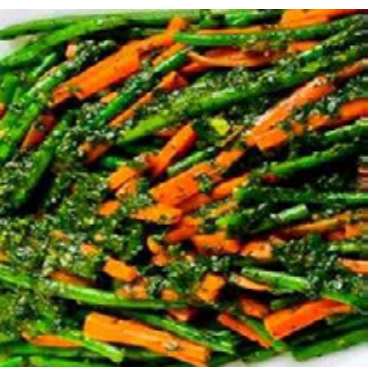

$p$

Fig. 3. Chlorophyll-containing vegetables and healthy nanoproducts of them: $a, b, c, d$-fresh spinach $(a)$ and healthy product of it: sorbets $(b)$, nanodrinks (c), soup-puree $(d), e, f, g, h$ - fresh

broccoli $(e)$ healthy products of it: soup-puree $(f)$, sauce-dressing $(g)$, vegetable ragout $(h)$; $i, j, k, l$ - fresh Brussels cabbage $(i)$ and healthy products of it: soup-puree $(j)$, sauce-dressing $(k)$, vegetable ragout $(l), m, n, o, p$ - fresh leguminous haricot $(m)$ and healthy products of it: soup-

puree $(n)$, sauce-dressing $(o)$, vegetable ragout $(p)$

\section{1. Experimental procedures}

The studies of the influence of steam-thermal processing of contents of chlorophyll and other BAS in fresh samples of CCV: broccoli, spinach, Brussels cabbage, green leguminous haricot bean were carried out in the steam-convectomat («Unox», Italy). The steam-processing was real- 
ized in the stove at temperature $105,110,115,120,125,130{ }^{\circ} \mathrm{C}$ to product temperature $70,75,80$, $90,100^{\circ} \mathrm{C}$. The processing duration was 1, 5, 7, 10 minutes. Experimental samples of CCV were preliminarily prepared (washed, inspected, cut, dried) and put as the layer with thickness $3 \ldots 5 \mathrm{~cm}$ depending on raw material type on the tray of the steam-convectional stove. The temperature in it, inproducts and duration of $\mathrm{CCV}$ processing in the chamber were set by determining regimes of steam-thermal processing that give a possibility to preserve chlorophylls of the initial raw materials and to transform it in the free form maximally. The fine-dyspersed comminution was realized in the cutter («Robot Coupe», France).

The quality by the content of main BAS was determined in fresh CCV (broccoli, spinach, Brussels cabbage, green leguminous haricot bean), thermally processed ones and also in fine-dyspersed purees of CCV.

The control was realized by contents of biologically active substances:

- Chlorophyll $\mathrm{a}$ and $\mathrm{b}$ was determined by the spectrophotometric method in acetone extracts of experimental samples. This method is based on the difference of maximums in absorption spectrums of chlorophylls a and $b$ in the red area $[9,10]$.

- L-ascorbic acid was determined by the method of visual and potentiometric titration by the solution of 2,6- dichlorophenolindophenolate $\mathrm{Na}[9,10]$.

- $\beta$-carotene was controlled by Muri method after separating carotene from a product by the organic dissolver and its cleaning from associated dyeing substances using colon chromatography $[9,10]$.

- Low-molecular phenol compounds (by routin and chlorogenic acid separately) were determined by the colorimetric method of Folin Denis in recalculation by chlorogenic acid [9, 10].

- Tanning substances (by tannin) were determined by the titrometric method in recalculation by tannin. The method is based on the ability of tanning substance to oxidize at the indigo carmine indicator $[9,10]$.

For controlling BAS in research objects, there were used chemical, physical-chemical and spectroscopic research methods, represented in works $[1,9,10]$.

\section{Results}

At conducting the model studies, it was experimentally established, that the steam-thermal processing of chlorophyll-containing vegetables at chamber temperature $105{ }^{\circ} \mathrm{C}$ and product one $70 \ldots 75^{\circ} \mathrm{C}$ during $5 \mathrm{~min}$ results in preservation of chlorophylls a and $\mathrm{b}$, carotene and other biologically active substances and their more full separation from the hidden form. Thus, comparing with fresh $\mathrm{CCV}$, the mass share of chlorophylls a and b and carotene increases $1,3 \ldots 1,4$ and 2 times, respectively at the aforesaid regimes of steam-thermal processing. It was demonstrated, that at the further fine-dyspersed comminution of steam-thermally processed chlorophyll-containing vegetables, the additional increase of the mass share of hidden BAS (chlorophylls a and b, carotene, phenol compounds and so on) take place. Comparing with fresh raw materials, the increase of chlorophylls $a$ and $b$ and carotene is $2 \ldots 2,1$ and 2,0..3,3 times, respectively.

Based on the obtained results of the experimental studies, there was developed the new method of preserving and maximal extraction of chlorophylls from chlorophyll-containing vegetables (broccoli, spinach, Brussels cabbage, green leguminous haricot bean) at obtaining healthy nanoproducts. The new methods differ from traditional ones by the complex use of the processes of thermodestruction (at steam-thermal processing), mechanodestruction and non- enzymatic catalysis (at fine-dyspersed comminution) of $\mathrm{CCV}$, using the new equipment for steam-thermal processing and comminution.

The obtained fine-dyspersed purees of CCV are in the easy-digestible nanosize form. The quality of obtained fine-dyspersed purees exceeds the one of purees, obtained by traditional technologies by BAS contents and technological characteristics.

The obtained fine-dyspersed purees of chlorophyll-containing vegetables were used as improvers of chlorophylls and other BAS at developing the green line of healthy nanoproducts: soups-purees, nanodrinks, nanosorbets, sauces-dressings, sauces-deeps, ice-cream, snacks and so 
on. It was demonstrated, that new products exceed existing analogues of products, obtained using traditional processing methods and technologies by BAS content (chlorophylls, $\beta$-carotene, L-ascorbic acid, phenol compounds).

\section{Conclusions}

There was developed the new method of getting healthy products of chlorophyll-containing vegetable (CCV), steam-thermally processed (by hot steam) in the steam-convectional stove and fine-dyspersated with high contents of chlorophylls and other BAS and prebiotics. The method is based on the complex effect of processes of thermodestruction, mechanodestruction and non-enzymatic catalysis on raw materials at fine-dyspersated comminution.

It was demonstrated, that at steam thermal processing of chlorophyll-containing vegetables $(\mathrm{CCV})$ in the steam-convectomat during 5 minutes, there takes place not only preservation of chlorophylls a and $\mathrm{b}$, but more full separation (in 1,33 ..1,4 times) from the hidden (bound) form, comparing with fresh vegetables. There was elucidated the mechanism of this process. The more full separation of hidden forms of $\beta$-carotene ( 2 times more than in fresh CCV) takes place in parallel.

It was established, that the essentially more effect of separating hidden forms is observed at fine-dyspersed comminution of steam-thermally processed CCV. It was demonstrated, that thermally processed nanoproducts of CCV contain 2...2,1 more chlorophylls a and b and 2,0...3,3 more carotenoids in the bound form than fresh vegetables, more than it was possible to extract by traditional methods till now.

The quality of obtained new types of fine-dyspersed steam-thermally processed purees of $\mathrm{CCV}$ exceeds one of known analogues, obtained by traditional methods by contents of chlorophylls $\mathrm{a}$ and $\mathrm{b}, \beta$-carotene and other BAS, which are in nano-size easy-digestible form.

The obtained fine-dyspersed purees of chlorophyll-containing vegetables were used as improvers of chlorophylls and other BAS at developing the green line of healthy nanoproducts: soups-purees, nanodrinks, nanosorbets, sauces-dressings, sauces-deeps, ice-cream, snacks and so on. It was demonstrated, that new products exceed existing analogues of products, obtained using traditional processing methods and technologies by BAS content (chlorophylls, $\beta$-carotene, L-ascorbic acid, phenol compounds).

\section{References}

[1] Pavlyuk, R. Yu., Pogarska, V. V., Radchenko, L. O., Pavlyuk, V. A., Tauber, R. D., Tymofieieva, N. M., Bessarab O. S. et. al. (2017). Novyi napriamok hlybokoi pererobky kharchovoi syrovyny. Kharkiv: Fakt, 380 .

[2] Wu, Z.-M., Wang, L., Zhu, W., Gao, Y.-H., Wu, H.-M., Wang, M. et. al. (2017). Preparation of a chlorophyll derivative and investigation of its photodynamic activities against cholangiocarcinoma. Biomedicine \& Pharmacotherapy, 92, 285-292. doi: 10.1016/j.biopha.2017.05.052

[3] Burana-osot, J., Soonthornchareonnon, N., Hosoyama, S., Linhardt, R. J., Toida, T. (2010). Partial depolymerization of pectin by a photochemical reaction. Carbohydrate Research, 345 (9), 1205-1210. doi: 10.1016/j.carres.2010.04.007

[4] Derrien, M., Badr, A., Gosselin, A., Desjardins, Y., Angers, P. (2017). Optimization of a green process for the extraction of lutein and chlorophyll from spinach by-products using response surface methodology (RSM). LWT - Food Science and Technology, 79, 170-177. doi: 10.1016/j.lwt.2017.01.010

[5] Global Strategy on Diet, Physical Activity and Health: report of a Joint WHO/FAO/UNU. Expert Consultation (2010). Geneva: World Healt Organization.

[6] Limantara, L., Dettling, M., Indrawati, R., Indriatmoko, Brotosudarmo, T. H. P. (2015). Analysis on the Chlorophyll Content of Commercial Green Leafy Vegetables. Procedia Chemistry, 14, 225-231. doi: 10.1016/j.proche.2015.03.032

[7] Pavlyuk, R., Pogarska, V., Radchenko, L., Roman, D. T., Timofeyeva, N., Kotuyk, T. (2016). The new method of processing of carotene-containing vegetables for the production of nanoproducts using combi-steamers and fine-dispersed comminution. EUREKA: Life Sciences, 3, 44-49. doi: 10.21303/25045695.2016.00146 
[8] Pogarska, V., Pavlyuk, R., Tauber, R. D., Pogarskiy, A., Berestova, A., Kravchuk, T. et. al. (2017). Development of the extraction method of inactive forms of pectin substances from fruits to easy-digestible active form during the obtaining of nanofood. EUREKA: Life Sciences, 6, 57-64. doi: 10.21303/25045695.2017.00520

[9] Kirik, I. M. et. al. (2009). Parokonvektsionnyi apparat dlya ob"ektov obshhestvennogo pitaniya. Innovatsionnye tekhnologii v pishhevoy promyshlennosti, 394-401.

[10] Kutkina, M., Fedinishina, E. (2007). Parokonvektomat: znay i umey: rekomendatsii po teplovoy obrabotke kulinarnoy produktsii raznykh vidov. Pitanie i obshhestvo, 10, 10-12.

\title{
RESEARCH OF INFLUENCE OF POTASSIUM-RICH DIETS ON THE PHYSICAL PERFORMANCE OF STUDENTS
}

\author{
Olga Simakova \\ Department of technology in a restaurant economy that hotel and restaurant business \\ Donetsk National University of Economics and Trade named after M. I.Tugan-Baranovsky \\ 16 Tramvaina str., Kryvyi Rih, Ukraine, 50005 \\ Simakova@donnuet.edu.ua \\ Yurii Korenets \\ Department of technology in a restaurant economy that hotel and restaurant business \\ Donetsk National University of Economics and Trade named after M. I.Tugan-Baranovsky \\ 16 Tramvaina str., Kryvyi Rih, Ukraine, 50005 \\ korenets_y@donnuet.edu.ua \\ Tatiana Yudina \\ Department of Technology and the organization of restaurant business \\ Kyiv National University of Trade and Economics \\ 19 Kyoto, str., Kyiv, Ukraine, 02156 \\ olegdmu@rambler.ru \\ Iryna Nazarenko \\ Department of technology in a restaurant economy that hotel and restaurant business \\ Donetsk National University of Economics and Trade named after M. I.Tugan-Baranovsky \\ 16 Tramvaina str., Kryvyi Rih, Ukraine, 50005 \\ Nazarenko@donnuet.edu.ua \\ Iuliia Goriainova \\ Department of technology in a restaurant economy that hotel and restaurant business \\ Donetsk National University of Economics and Trade named after M. I.Tugan-Baranovsky \\ 16 Tramvaina str., Kryvyi Rih, Ukraine, 50005 \\ goryaynova@donnuet.edu.ua
}

\footnotetext{
Abstract

The aim of the work is the scientific substantiation and experimental support of the expedience and use of potassium-cationic water for improving the bread quality and the study of the influence of potassium-rich diets on the physical performance of students. There was studied the influence of potassium cations on the activity of proteolytic enzymes of wheat flour. It was established, that at using potassium-cationic water, the output of wet gluten $(35,1 \%)$ essentially increases, at that the output of dry one $(8,4 \%)$ decreases to the same extent that is a positive factor in the bakery technology. It was proved that enriching the vital medium of bakery yeast by potassium cations essentially activates their ability to hydrolysis of maltose that favors activation of the process of gassing (maltase activity - 35,1 min). The process of gassing influences the speed of dough-conduction and ready bread quality, especially volume $(357,7,100 \mathrm{~g} / \mathrm{ml})$, porosity $(79,1 \%)$ and crumb ability to compression (33,5 c.u.). It was established, that consumption of bread, pro-
} 